\title{
HOMEOPÁTIA - ŐSELEFÁNT A MODERN GYÓGYÁSZAT PORCELÁNBOLTJÁBAN
}

\section{HOMEOPATHY: ANCIENT ELEPHANT IN THE CHINA SHOP OF MODERN MEDICINE}

\author{
Boldogkői Zsolt \\ Dsc, intézetvezető igazgató, Szegedi Tudományegyetem Általános Orvostudományi Kar Orvosi Biológiai Intézet \\ boldogkoi.zsolt@med.u-szeged.hu
}

\begin{abstract}
ÖSSZEFOGLALÁS
A homeopátiát az alternatív orvoslás királynőjének is nevezik, feltehetően a népszerűsége, az abszurd elvei és talán az orvosi szakma érintettsége is predesztinálják e névre. Valamilyen rejtélyes ok miatt a fejlett világ törvénykezése szemet huny e nyilvánvaló átverés felett, noha itt nem csupán egy ártalmatlan áltudományos teóriáról van szó, hanem egy hatástalan "gyógymódról", amely betegek egészségét veszélyeztetheti, ha a konvencionális gyógyítás helyett alkalmazzák, vagy ha nem megfelelő módon állítják elő a készítményeket.
\end{abstract}

\section{ABSTRACT}

Homeopathy is called the queen of alternative medicine due to its popularity and absurd tenets, as well as the fact that physicians are involved in the practice of this method. For a mysterious reason, the legislation of the developed world tolerates this apparent scam, although, homeopathy is not only a pseudoscience but also an ineffective "therapy", which can endanger the health of patients using it instead of the conventional methods, or if the remedies are improperly prepared.

Kulcsszavak: homeopátia, alternatív orvoslás, áltudomány

Keywords: homeopathy, alternative medicine, pseudoscience 


\section{BEVEZETÉS}

A cikk témája a homeopátia, melyet hívei az alternatív orvoslás királynőjének is neveznek, feltehetően a népszerüsége, abszurd elvei és talán az orvosi szakma érintettsége is predesztinálják e névre. Bár itt nem csupán egy ártalmatlan áltudományos teóriáról van szó, ismeretlen okokból a fejlett nyugati világ törvénykezése szemet huny e nyilvánvaló átverés felett, noha nem csupán egy hatástalan „gyógymódról” beszélünk, amely betegek egészségét veszélyeztetheti, ha a konvencionális gyógyítás helyett alkalmazzák, vagy ha nem megfelelö módon állítják elő a készítményeket. Hasonlóan számos más alternatív módszerhez, a homeopátia is benntartja még büzös lábát a tudomány perifériáján, mivel még ma is jelennek meg pozitív eredmények a hatásosságot illetően egyes, alacsony presztízzsel rendelkező szaklapokban. A kiszorító hadművelet azonban elkezdődött: egyre-másra alkalmaznak szisztematikus analíziseket (Mészáros, 2014), melyek rendre a homeopátia hatástalanságát hozzák ki eredményül, s a szakma is egyre hangosabban követeli a jogi szigorítást. Ebben az írásban nem követem az egzakt tudományos tárgyalásmódot, hiszen ezzel rangot adnék a sületlenségnek.

\section{A MODERN ORVOSLÁS A TUDOMÁNYON ALAPUL}

A tudományt gyakran azonosítják az általa alkalmazott módszerrel, melynek lényege, hogy a hipotéziseinket kísérletesen és/vagy megfigyelések útján teszteljük. A tudomány azonban jóval több ennél, hiszen állításai koherens rendszert képeznek, és jelenbeli ismeretei iránymutatást adnak a jövőbeli kutatásokat illetöen. A tudomány önkorrekcióval rendelkezik: a téves elgondolások előbb-utóbb kiszóródnak a testéből, függetlenül attól, milyen tekintéllyel rendelkező tudós vagy kutatócsoport nevéhez kötődik az adott teória. Az autentikus orvoslás a tudományon alapul. A modern gyógyászat kialakulásának kezdetén a megfigyelések nem voltak elég megbízhatóak, ezért történhetett meg, hogy áltudományokon alapuló elképzelések (például a testnedvek tana) vagy kezelési módszerek (például az érvágás, a purgálás és a köpölyözés) terjedtek el. A jelenlegi orvoslás is tartalmaz ugyan igazolatlan hatásosságú és ismeretlen mechanizmusokon alapuló terápiákat, de a tudományos progresszió egyre inkább kiszorítja ezeket. Korábban a gyógyszerek jelentős része a természet patikájából származott, és rendszerint véletlenül fedezték fel a gyógyító hatást, például úgy, hogy az alkalmazás során a szer mellékhatása bizonyult terápiásnak egy másik betegségre. Ma már egyre inkább az a trend érvényesül, hogy előbb megismerjük a biológiai hátteret, majd e tudás birtokában dolgozzuk ki a hatásos terápiát. A modern farmakológia a hagyományos kismolekulájú gyógyszereket már föleg számítógépes modellezéssel tervezi, és közeleg a szekvenciaspecifikus gyógyszerek kora. 


\section{AZ ÁLTUDOMÁNYOK}

Az áltudományok hibás koncepciókon alapulnak, megfigyeléseket, kísérleteket rendszerint nem végeznek, vagy ha igen, azok nem állják ki a tudományosság próbáját. Az áltudományos teóriák eredhetnek alapító atyák „,bölcsességéből”, vagy feltételezett népi megfigyelésekből. Ezek az elképzelések a modern tudomány korában kifejezetten bizarrnak tünnek, néhányuk esetében mégis társadalmi és jogi tolerancia létezik velük szemben, sőt, egyeseket állami forrásokból is támogatnak. Az áltudományon alapuló orvoslásnak vannak olyan ágai, melyek egyetemek hivatalos tanrendjében szerepelnek, egyeseket pedig bizonyos országokban csak orvosi diplomával gyakorolhatnak. E tények tragikusan romboló hatással vannak a tudományos orvoslás presztízsére, nem beszélve arról, hogy veszélyeztetik a páciensek egészségét is, vagy közvetlenül, vagy azáltal, hogy a hagyományos terápiák helyett választják ezeket.

\section{ALTERNATÍV ORVOSLÁS}

Az alternatív orvoslás eredendően az ortodox medicinával szemben határozta meg magát. A jogi szigorodás következtében azonban ma már jóval óvatosabb ennél, s szívesebben alkalmazza a komplementer és alternatív medicina (CAM) kifejezést. Söt, a hagyományos orvosláshoz való intenzívebb dörgölődzés jegyében sokan az integratív medicina (IM) kifejezést használják, azt sugallván, hogy a két ,egyenrangú” megközelítésnek végre össze kellene fognia a hatékony orvoslás érdekében. A szómágia azonban a lényegen jottányit sem változtatott: gyakran áltudományos tételek szolgálnak a terápiák elméleti alapjául, a gyakorlatban pedig jó esetben nem igazolt a hatásosságuk, a főbb ágak esetében pedig ma már kísérletes bizonyítékokkal rendelkezünk azt illetően, hogy nem müködnek.

\section{KUTYAHARAPÁST SZŐRIVEL}

E népszerü ,gyógymódot” Samuel Hahnemann élesztette fel halottaiból cirka 250 ével ezelött. A homeopátia hasonlóság elve ugyanis egészen a görög időkig nyúlik vissza, állítólag már Hippokratész is alkalmazta a gyógyításban i. e. 400 körül. Az elv lényege, hogy - szemben a hagyományos gyógyászattal - nem a betegségek ellenében kell terápiás hatást gyakorolni, hanem olyan készítményeket kell előállítani, melyek ugyanolyan tüneteket váltanak ki, mint amilyeneket a gyógyítani kívánt betegség produkál. Az unalomig ismert történet szerint Hahnemann a malária ellenszerét, kinint fogyasztott, 
és ezután az e kórra jellemző tüneteket (láz, remegés, szívdobogás, álmosság stb.) figyelt meg önmagán. Abban az időben az egyetlen személyen végzett kísérlet még nem szúrta ki a biostatisztikusok szemét, ezért a német orvos egy komplett filozófiát gyárthatott az önmegfigyelése köré. Innentől a homeopátiás protokollok szerint készített hagyma a nátha ellen, a darált méhecske kivonat az allergia ellen, a Berlini Fal oldata pedig a lelki egyensúly megóvása érdekében dolgoztak a beteg szervezetben. Szkeptikus kutatók megismételték Hahnemann alapkísérletét, de sajna rajtuk nem jelentkeztek az említett tünetek. A homeopátiát azonban e kísérletek kudarca nem döntötte romba. Tegyük hozzá, szerencsére, mert azonmód homeopátiás szert készítettek volna a romokból, hogy az stabilizálja a homeopátiába vetett megingott hitet. Hihetetlen, de valóban létezik hitstabilizáló készítmény, Walnut (dió) a neve. A készítmény ötlete Edward Bachnak - a Bach-virágterápia atyjának - fejéböl pattant ki. A dió az emberi agyra hasonlít, ezért homeopátiás oldata az észszerűség egyfajta szimbólumaként, a fizikai világ oksági folyamatain keresztül fejti ki jótékony hatását. Idézzük Bachot szó szerint: a Walnut készítmény azok számára ajánlatos, „akik határozott eszményekkel és ambíciókkal rendelkeznek, de néha csábítást éreznek arra, hogy eltérüljenek az eredeti eszméiktől, céljaiktól, és mások elképzeléseit kezdjék el követni. A készítmény állandóságot és külső hatások elleni védelmet biztosít." A szimbólumok ereje mutatkozik meg például a Vacuum nevü készítményben, hiszen ezt a semmiből készült szert érdemes szedni, ha lelki természetủ „,vákuumot” érzünk magunkban. A mobiltelefonok elektromágneses teréből létrehozott készítmény szimbolikáját pedig már csak kivételes intelligenciával lehet felfogni. Itt a tejcukorport egy Cellnet szolgáltatóhoz kapcsolódó Ericsson GH337 készülék sugárzásának tesznek ki, egy másik cukoradagot pedig pontosan két óra tizenhat percig az Orange szolgáltatóhoz kapcsolódó Nokia 5.1 készülék sugárzásával kezelnek. A két port ezután összekeverik. Nem tudni pontosan, hogy e szer mire lehet jó, csak az biztos, hogy érdemes szedni. Legyünk igazságosak, a homeopátiás szerek többsége nem ilyen blőd alapanyagokból, hanem gyógynövényekből készül. Sokan ezért hiszik azt, hogy a homeopátia a gyógynövény-terápia egyik ága. A helyzet azonban az, hogy teljesen mindegy, miből indulunk ki, ha végül nulla dózishoz jutunk. Nézzük meg, miért!

\section{ZÉRÓ DÓZIS ÉS VÍZEMLÉKEZET}

Hahnemann érzékelte a korabeli gyógyászat kedvezőtlen sajátságait, melyek legfontosabbika - a hatástalanság mellett - a kezelések erős mellékhatása volt. Úgy vélte, elegendő lesz, ha a "hatóanyagot” kellö mértékben hígítja, s így a mellékhatások kiiktathatók. A logika alapvetései már a homeopátia hajnalán is 
léteztek, így Hahnemann-nak tudnia kellett volna, hogy a mellékhatás-mentesítés ilyetén való megvalósításának magára a hatásosságra is befolyással kell lennie. Nem beszélve arról, hogy a kiinduló anyagokat sem nevezhetjük hatóanyagnak, hiszen a gyógyulásra cseppnyi hatással sem voltak. A kíméletesség ma is a homeopata orvosok kedvenc kifejezése, melyet a hatásos gyógykezelések mellékhatásaival állítanak szembe. Egy tipikus hígítás a C200, ami kétszáz egymást követő százszoros hígítási lépést jelent. Érzékeltetésképpen, ha az egész világegyetemet egy gigantikus lombikba helyeznénk, C53-as hígításnál már egyetlen részecske sem maradna benne, tehát a további hígítás értelmetlen. Van olyan készítmény, amit C100 000-szeres hígítással kapnak meg. A hígításokat ma már gépekkel végzik ipari körülmények között. Az atomelmélet a 20. század terméke, ezért Hahnemann nem tudhatta, hogy a hígítások egy bizonyos mértéken túl teljesen értelmetlenek, hiszen a részecskék diszkrét természetủek, azaz nem darabolhatóak végtelenül, s egy idő után a kiinduló anyagból már egyetlen molekula sem marad a vízben. A mester azon követői, akik valamelyest figyelembe vették a tudomány alapállításait, megérezvén az intellektuális csapdát, egy mentő ötlettel álltak elő: nem szükséges a hatóanyag fizikai jelenléte, a víz ugyanis emlékszik rá, s az emlékekre a hígítás nincs hatással. Nem tudjuk, miként tárolódik a gyógyító memória, csak annyi biztos, hogy olyasféle kvantumemlékezetről van szó, amilyen mélységekbe a szkeptikus tudomány soha nem jut el. Van azért itt néhány probléma. Az első, hogy a víz a több milliárd éves emlékeinek tárolására nem képes, sőt valójában semmire sem emlékszik. Továbbá, a víznek nem csupán emlékeznie kell, hanem egy olyan programcsomagot kellene tárolnia, amely képes a szervezetet áthangolni a beteg állapotból az egészségessé válás útjára, ami nyilvánvaló képtelenség. Ráadásul ezt az információt a párolgása során át is kell adnia egy cukorgolyócskának, amit a páciensek majd bevesznek.

\section{ENERGETIZÁLÁS}

Egy készítmény nem lesz ám magától erős hatású, ehhez kultikus mozdulatokkal ütögetni kell az oldatot minden hígítási lépést követően meghatározott protokoll szerint, egy adott felületen. De vigyázni kell, a túl sok ütögetés veszélyes erősségủvé teheti a szert! Ezt a jelenséget maga Hahnemann figyelte meg. Nevezetesen, azt vette észre, hogy minél messzebb lakik egy páciens a rendelőjétől, annál hatásosabb a szer. Hogy miért? Mert abban az időben nem voltak olyan tükörsimák az utak, mint ma, a lovas kocsik akkor még macskakövön zötykölődtek. A mester azonnal értesítette az őt követő orvosokat és a pácienseit, hogy a homeopátiás szereket ne hordják a zakójuk mellényzsebében, mert hatásuk az egészséget veszélyeztető mértékben felerősödhet. 


\section{A HOMEOPÁTIA AZ ÉLETERŐT MOZGÓSÍTJA A MIAZMA ELLEN}

Hahnemann a homeopátiát eredetileg két, ma már áltudományosnak nevezendő cél elérése érdekében alkalmazta. Elöször is, abban az időben még élt és virágzott a vis vitalis elmélet, amely szerint a szervezetet egy misztikus energia, az életerő tartja életben. A homeopátia feladata e nem létező erő mozgósítása a gyógyulás érdekében. Mi fenyegette leginkább az egészséget abban az időben? A miazma. Akkoriban még nem tudtak a kórokozók létezéséről, $\mathrm{s}$ az volt az elképzelés, hogy egy mindent átható titokzatos anyag, a miazma leselkedik az egészséges szervezetre, s teszi azt beteggé. A miazmát olyannak képzelték el, mint ami mindenütt jelen van, ezért nem lehet elrejtőzni előle. Ez egy tragikus tévedés volt különösen világjárványok esetén, hiszen a steril körülmények megteremtése megállíthatta volna a kórokozók terjedését, vagy legalább mérsékelte volna az áldozatok számát. A homeopátia tehát eredendően egy nem létező erőt volt hivatott mozgósítani egy nem létező célpont megsemmisítése ellen.

\section{A HOLISZTIKUS GYÓGYMÓD}

Szemben a hagyományos terápiákkal, melyek a betegség megszüntetését vagy a tünetek enyhítését tủzik célul, a homeopátia az egész szervezetre hat. E sztereotip érvelést hallhatjuk folyton a homeopátia teoretikusaitól. A helyzet a következő: a konvencionális orvoslás valójában holisztikus, már amennyiben hatásos terápiát alkalmaz, hiszen a beteg szerv meggyógyulása az egész szervezetre jótékony hatással van. Ezzel szemben a homeopátia legfeljebb placebohatást képes elérni, melynek fontossága a gyógyulásban jelenleg vitatott. A beteg közérzetét javíthatja, a fájdalom és esetleg a gyulladásos folyamatokra is kedvező hatással lehet, de komoly betegségek esetén teljesen hatástalan. Annyi azonban bizonyos, hogy a hazugságra alapozott hit erkölcstana egy olyan ingoványos terület, melyre ebben az írásban nem merészkedünk.

\section{AZ EGYSZERŰSÉG ELVE}

Hahnemann híres tigris hasonlata szerint, „ha értjük, hogy miért nem élhet két tigris egy helyen, akkor megértjük azt is, miért lehet egyszerre csak egyetlen gyógyszert alkalmazni egy betegségre". A klasszikus homeopátia korában az egyszerüség elve volt az uralkodó. A világ azonban fejlődik, s jelenleg már a komplex homeopátia korában élünk. A változás lényege, hogy egyszerre több 
homeopátiás készítményt is fogyaszthatunk bajainkra vagy azok megelözése érdekében. Senki ne tételezzen fel sanda anyagi megfontolásokat, a homeopátia az emberért van, nem a gyártók, a receptírók és a szert patikákban árulók anyagi gyarapodásáért.

\section{SZER EGY NEM LÉTEZŐ BAKTÉRIUMBÓL}

Éljünk gyanakvással, ha egy olyan szerről hallunk, melyet nem létező alapanyagból állítottak elő. A legkelendőbb homeopátiás készítmény, az Oscillococcinum pontosan ilyen. A sokmilliós áldozatot követelő spanyolnátha idején egy sebészorvos, Joseph Roy az elhunytak véréből gömbszerủ oszcilláló baktériumokat izolált, melyet elnevezett Oscillococcusnak. Érdekes módon, az angol sebész ugyanezeket a mikroorganizmusokat vélte felfedezni a bárányhimlö, az ekcéma, a reuma és számos egyéb betegségben szenvedő páciens szervezetében. Az irodalomban nehezen nyomon követhető, miért éppen a pézsmakacsa májából izolálta Roy a kórokozót, és készített ebből homeopátiás szert. Az Oscillococcinum széles hatásspektrumú, szinte minden kórra hat, mégis elsősorban az influenzajárványok idején folyik masszív reklámhadjárat a médiában és az óriásplakátokon, hogy feltétlenül szedjék az emberek. Nos, az Oscillococcus baktériummal az a fö probléma, hogy nem létezik, csak spekulálni lehet, mit láthatott mikroszkópjában szinte az összes megvizsgált mintájában a sebészdoktor. Fura, hogy még soha egyetlen figyelmeztetés sem érkezett egyetlen illetékes hatóságtól sem, hogy itt egy nagy átverésről van szó, s hogy az influenzajárvány veszélyeztetettjei nehogy kizárólag egy hatástalan készítményben bízzanak. Nem is figyelmeztetés kellene, hanem büntetőjogi eljárás indítványozása.

\section{ANYAG ÉS INFORMÁCIÓ}

A homeopátiában összekeveredik a fizikai és a szimbolikus létezés, az utóbbiról azt feltételezik, hogy ugyanolyan oki hatásokat képes kiváltani, mint az előbbi. Egyszerủ szimbolizmusra épül a Sepia nevü szer, amelyet a tintahal szépiacsontjából készítenek. A készítmény női bajokra való hatásásosságát az a tény biztosítja, hogy a „csont” hasonlít a petefészekre. Ugyanígy, a dió hasonlósága az emberi agyhoz az ebből készített szert alkalmassá teszi kognitív problémákra való terápiás hatás kiváltására. A vándorsólyom (Falco peregrinus) esetében a szabadság eszméjének szimbolikája már jóval áttételesebb. A hajóroncs (Shipwreck) logikája pedig már egészen bizarr oksági láncolatot feltételez: a süllyedés és fulladás által kiváltott rémület valahogyan integrálódik a hajó faszerkezetében, s egy ebből készített végtelen hígítású anyag, melyet ütögetéssel erősítenek, a víz, majd 
a tejcukor memóriájává válik, s elfogyasztva az emberi agy félelemközpontjának (amygdala) aktivitására hat mérséklő hatással, így szüntetvén meg az aggodalmat és a depressziót a homeopátiahívő páciensekben.

\section{A BIZARR ÖTLETEK VÁLNAK GYÓGYSZEREKKÉ}

A homeopátiás szerek tesztelése látszólag a tudományos módszer nyomdokain halad, hiszen még placebokontrollt is alkotnak. Néhány probléma azért akad itt. Az egyik az, hogy maga a felmerülő ötlet a kiindulási anyag és a gyógyhatás összefüggéséről egy nagy badarság. Továbbá, nem folynak egzakt vizsgálatok, hanem csupán a szer szedése során tapasztalt szubjektív beszámolókat értékelik, melyek között egészen abszurd dolgok is lehetnek. Ráadásul nem magát a készítményt tesztelik, hanem annak egy hígítatlan vagy alacsony hígítású oldatát. A tesztelés során pedig nem azt vizsgálják, vajon egy szer kedvező hatással van-e egy adott betegség gyógyulására, hanem hogy az képes-e tüneteket előidézni egészséges embereknél. Egy modern megközelítés szerint nem szükséges lenyelni a szert, elegendő, ha csupán meditálnak róla. A vizsgálatok természetesen nem elégítik ki a precíz statisztikai követelményeket, mivel például a vizsgálati mintaszám nagyon alacsony, és nem alkalmaznak randomizált kontrollokat sem. A kiváltott tünetek összessége alapján állítják össze az ún. gyógyszerképet. A szerek listáját a gyógyszerképekkel a Materia Medicák tartalmazzák.

\section{DIAGNÓZIS ÉS TERÁPIA A HOMEOPÁTIA VILÁGÁBAN}

A homeopátiás doktorok a betegség diagnózisát a kórelőzmény és a vizsgálat során megfigyelt tünetek alapján állítják fel, ezt nevezik betegségképnek. A terápia megállapítása egészen egyszerü: illeszteni kell a betegségképet a Materia Medicákban fellelhető gyógyszerképpel. Itt a fö probléma, hogy ez a megfeleltetés igen erős szubjektivitással terhelt. Persze, ez az aggály csak akkor merülhetne fel, ha az előző lépéseknek lenne értelmük. Egy eredeti módszer szerint az illesztéshez szükséges intellektuális terhelést mérsékelhetjük, ha egy ingát alkalmazunk a megfelelö terápia nagykönyvben való felleléséhez.

\section{A TUDOMÁNY KALANDORAI}

A tudománynak a legtöbbet maguk a tudósok árthatnak, ha butaságokhoz adják a nevüket. Jacques Benveniste (URL1) és munkatársai a homeopátiás hígítású IgE-ellenes antitestet állították elö, s ezzel - állításuk szerint - bazofil granulo- 
citák hisztamintermelését tudták előidézni. Az erről szóló tanulmányt a rangos Nature nevü lapban közölték le. A szaklap főszerkesztöjének azonban volt egy feltétele: a publikálást követően egy szakmai stáb fogja ellenőrizni az eredményeket a francia kutató laboratóriumában. Benveniste belement az alkuba, de nagyon meglepődött, amikor kiderült, hogy a delegációnak egy bủvész tagja is volt. A bủvész nem volt más, mint James Randi (URL2), aki egyébként arról híresült el, hogy egymillió dollárt ajánlott fel annak, aki hitelesen bizonyítani tudja egy paranormális jelenségről, hogy müködik (mindezidáig senkinek nem sikerült). Randi azonnal kiszúrta a hibát, ami az volt, hogy a technikus tisztában volt azzal, melyik minta mit tartalmazott, és ez befolyásolta az értékelését. Amint a nevek helyett kódok kerültek a fiolákra, a homeopátiás szer azonnal elveszítette a hatását. A téveszmék alaptermészetéhez tartozik, hogy nem szívesen adják meg magukat. Benveniste ahelyett, hogy beismerte volt a tévedését, inkább továbbfejlesztette az elméletét. Haláláig úgy vélte, hogy a homeopátiás készítményekkel nem szükséges közvetlenül érintkezni, a bennük rejlö információ telefonon vagy interneten is továbbítható. Luc Montagnier (URL3), a Nobel-díjas honfitárs, Benveniste-et a modern kor Galileiének nevezte, aki bátran szembeszállt korának szűklátókörűségével. Montagnier az AIDS vírusának felfedezéséért érdemelte ki a legmagasabb rangú tudományos elismerést, de idősödő elméjét megtámadta az ún. Nobel-betegség, melynek fö tünete a kínosan hamis elméletek hangoztatása. Montagnier ugyanis azt állította, hogy a víz akkor is megörzi a DNS információtartalmát, ha a homeopátiásan hígított oldat már egyetlen kettős spirál molekulát sem tartalmaz. Molekuláris laboratóriumban dolgozók ismerik e jelenséget, szennyeződésnek hívják. Az ún. PCR-technikával (URL4) igen kis mennyiségü DNS-t is képesek vagyunk felsokszorozni. Tehát elegendő egy apró kis kontamináció, ami igen gyakran előfordul, s nem szükséges az anyagnak információvá, majd újra anyaggá alakulnia ahhoz, hogy PCR-specifikus DNS terméket produkáljon. A misztikus elme azonban sohasem hátrál, hanem rendületlenül nyomul elöre. Montagnier is továbblépett a józan ész határain, s megalkotta a szignalizáció elméletét, mely szerint a DNS információtartalma teleportálás útján is képes terjedni. Az ember ilyenkor eltűnődik, az a sok-sok millió faj a Földön vajon miért vesződik oly szenvedélyesen a szexualitással, hiszen ha igaz a szignalizáció tana, akkor a fizikai kontaktus helyett elegendő lenne csak ábrándozni róla.

\section{FEHÉR KÖPENYESEK A HOMEOPÁTIA ZSOLDJÁBAN}

Néhány ezoterikus hajlamú kutatónál jóval nagyobb hatású az orvosok és a gyógyszerészek nagyszámú részvétele a homeopátia-bizniszben. A laikusok szemében e két szakma képviselői iránt igen nagy a bizalom, mellyel visszaélni nem lenne ildomos. Noha hatástalan, áltudományon alapuló terápiát alkalmazni betegeken 
súlyos bủncselekmény kellene hogy legyen, valamilyen ok miatt mégsem az, sőt, törvényesen végezhető tevékenységről van szó. Ráadásul a homeopátia igen gyakran oltásellenességgel és a konvencionális gyógyászat elleni bizalmatlanságkeltéssel is párosul, melyek egy orvos részéröl szintén veszélyes és tisztességtelen attitüdök. A homeopata orvosok nem mellesleg a tudományt is lejáratják, amikor vízemlékezetről, ezoterikus energiákról, biorezonanciákról és egyéb sületlenségekről beszélnek pácienseiknek.

\section{ÁTVERTEK VÉD- ÉS DACSZÖVETSÉGE}

Gondoljunk bele, milyen paradox lenne, ha a lopások és rablások áldozatai öszszefognának, és védelmükbe vennék a bủnelkövetőket. Nos, az alternatív orvoslás átvertjei éppen ezt teszik. Ök azok, akik a homeopátia elleni bármilyen megnyilvánulásra azonnal vehemens támadással reagálnak. Az érvelésük gyakran rendkívül arrogáns hangvételü, és nélkülözi a minimális tudományos ismereteket. Ez utóbbiról viszont sajnos nincs is tudomásuk. E laikusokkal vitatkozni nem érdemes, hiszen az észérvek hatástalanok, és az ember hirtelenjében a bünös gyógyszeripar fizetett ügynöke és egyben a tudományos haladás legfőbb akadálya lesz. A hívek - gyakran a szó szoros értelmében - Galileinek hiszik magukat, akik az igazság nevében szembeszállnak a kor téveszmeivel annak tudatában, hogy a jövő őket igazolja majd. Sajnos, ebben a történetben a szerepek felcserélődnek, hiszen Galilei a tudomány nevében szállt szembe egy tömegesen hitt téves nézettel, míg itt a tömeges téveszme száll szembe a tudományos igazsággal.

\section{A HOMEOPÁTIA NEM MÜKÖDIK}

A homeopátia alapelvei annyira abszurdak, hogy ha igazak lennének, újra kellene írni a természettudományos tankönyveket. Ennek ellenére a kutatók elvégezték a szokásos ellenőrző vizsgálatokat. Az alternatív orvoslásra a legnagyobb csapást az ún. szisztematikus analízisek és a metaanalízisek mérték. E vizsgálatok öszszegezik az adott témában megjelent publikációk adatait, ezáltal egy megbízhatóbb statisztikai alapsokaságot állítanak elő. Van azonban az adategyesítés előtt egy szürési lépés: megvizsgálják, hogy tudományos és statisztikai szempontból megfelelően volt-e kivitelezve a kísérlet, s ha nem, a konklúziótól függetlenül, a közleményt kiveszik a további analízisből. Ágazatoktól függően, az alternatív metodikák hatásosságáról szóló publikációk igen jelentős százalékban kerülnek a szemétkosárba. Így van ez a homeopátia esetében is. Sajnos, az adathamisítást és az egyéb csalási formákat, valamint az ún. fiókhatást (Goldacre, 2012) nem lehet kiküszöbölni e technikával. 
Edzard Ernst és kollégái egy szisztematikus analízis során arra a következtetésre jutottak, hogy a homeopátia nem rendelkezik gyógyhatással (Ernst, 2002). Egy fontos Cochrane-szemle (McCarney et al., 1998) és számos egyéb vizsgálat is kétséget kizáróan bebizonyította, hogy a homeopátia hatástalan a demencia, az asztma, az artritisz és a migrén ellen. A The Lancet egy 2005-ben megjelent metaanalízisében (Shang et al., 2005) Matthias Egger és kollégái hasonló konklúzióra jutottak: a homeopátia nem rendelkezik specifikus gyógyító hatással, csupán placebohatás kiváltására alkalmas. Egy újabb Cochrane-analízis (Vickers-Smith, 2006) az Oscilloccinummal kapcsolatban hozta ki azt az eredményt, hogy semmilyen empirikus adat nem támasztja alá e készítmény influenzaellenes hatását sem a megelőzésben, sem a terápiában. Egy további közlemény (Milazzo et al., 2006) szerint a homeopátia hatástalan a kemoterápia és radioterápia során fellépő mellékhatások enyhítésében. Ugyanez a hatástalanság jellemző az asztma és a felső légúti betegségek (Altunc et al., 2007) esetében is. A sort fölösleges folytatni, a komolyabb analízisek mind hatástalanságot hoznak ki eredményül. A publikációk egy része konklúzióként megállapítja, hogy a homeopátia közvetve ártalmas is lehet, ha a konvencionális kezelés alternatívájaként használják (például Posadzki et al., 2012).

A homeopata orvosok természetesen nem fogadják el a negatív eredményeket hozó vizsgálatokat. Az érveik során különféle összeesküvés-elméletek kerülnek elő, a cikkek és a jelentések íróit gyakran személyükben támadják, s inkompetenseknek állítják be őket. Egyébként is, állításuk szerint, a homeopátiás készítmények egyénileg hatnak, és az orvos-páciens személyes kapcsolata is fontos tényezö, ezért a statisztikai módszerek nem alkalmazhatók ezen a területen. Feltehetjük a kérdést, hogy akkor vajon mi értelme van a gyógyszerkép megállapításának, ha az a vizsgált személyekre egyénileg állapít meg igaz állításokat? Másrészt miért lehet gyógyszertárban homeopátiás szert kapni orvosi konzultáció és recept nélkül? Továbbá az a kérdés, hogy meggyógyul-e egy beteg vagy sem, egyszerü igen/nem kérdéssé redukálható.

\section{MEGENGEDŐ TÖRVÉNYEK}

Ha valakinek azt állítjuk, hogy az általunk ajánlott vagy árult termék müködik, noha ez hazugság, akkor erre a büntetö törvénykönyv megfelelő paragrafusai alkalmazhatók. Ha ezt a fajta átverést az egészségügyben tesszük, annak nincs semmi következménye. A homeopátiás szereket egyszerüsített vizsgálati eljárással gyógyszer kategóriába lehet sorolni. Az Európai Parlament (EP) és az Európa Tanács (ET) ajánlása magáévá tette azt az érvet, hogy a hígítás mértéke garanciát jelent arra, hogy a homeopátiás készítmények nem rendelkeznek toxikus hatással. Rendben, de miért nem kell azt igazolni, hogy gyógyhatással viszont rendelkez- 
nek? Továbbá, az EP és ET szerint ,a homeopátiás szerek egyénileg hatnak, ezért nem vizsgálhatók tudományos módszerekkel”. Szakmai szemmel nézve ez egy igen megdöbbentő hamis állítás.

\section{A SZAKMA TALPRA ÁLL}

Ausztrália nagyon aktív a homeopátiaellenes harcban: az ausztrál Nemzeti Egészségügyi és Orvosi Kutatási Tanács (National Health and Medical Research Council, NHMRC) nyilatkozata (NHMRC, 2015) szerint a homeopátia kizárólag a placebohatáson alapul. Érdekesség, bár nem meglepő, hogy a vizsgálatban alapul vett 1800 tanulmányból mindössze 225 felelt meg a szakmai követelményeknek. A rostán átment publikációk egyértelmüen negatív eredményt hoztak ki a homeopátia hatásosságát illetően. A Svéd Királyi Tudományos Akadémia állásfoglalása (Royal Swedish Academy, 2015) volt a következő állomás. A skandináv ország tudósai szerint a homeopátiás szereket ugyanolyan szabályok szerint kellene engedélyeztetni, mint a hagyományos gyógyszereket. Ehhez az állásfoglaláshoz csatlakozott a Magyar Tudományos Akadémia Orvosi Tanulmányok Osztálya ellenszavazat nélkül (MTA, 2015). Legújabb fejleményként az Európai Tudományos Akadémiák Tudományos Tanácsadó Testülete (EASAC) fejtette ki álláspontját (MTA, 2017), mely szerint ,az irodalom kimerítő áttekintése után sem állnak rendelkezésre a homeopátiás termékek és eljárások hatékonyságát alátámasztó, tudományosan elfogadható, kellőképpen meggyőző és reprodukálható bizonyítékok". Sajnos a tudományos közösség egységes és egyértelmü kiállása a ráció mellett még távolról sem az utolsó pont a történet végén, e problémát az EU politikai és jogi állásfoglalása oldhatná meg végérvényesen.

\section{A HOMEOPÁTIA ÁLDOZATAI/VESZÉLYEI}

A homeopátia látszólag ártalmatlan, gyógyításra szánt módszer. Viszont, ha a konvencionális kezelés helyett alkalmazzuk, veszélyessé válhat. A legfőbb veszély nem elsősorban az, hogy a homeopata orvosok kizárólagosan homeopátiás terápiát alkalmaznak komoly betegség esetén (legalábbis reménykedni lehet, hogy nem ez a helyzet), hanem az, hogy maga a beteg dönthet saját ismeretei alapján a homeopátia mellett. Ezért nagyon fontos, hogy a laikusok hiteles ismeretek birtokában legyenek. Az orvosok részvétele ebben az üzleti tevékenységben pedig azért súlyos felelőtlenség, mert állásfoglalásukkal hitelesítik a hamis információkat. További veszélyforrást jelent az, ha a szereket nem szabályosan készítik, azaz véletlenül vagy szándékosan hígítatlan vagy alacsony hígítású formában állítják elő ezeket, s így a hatóanyag valóban hatással lehet a szervezetre. 
Például a közelmúltban tíz gyermek meghalt, és sokan megbetegedtek homeopátiás szer fogyasztását követően, mivel valószínüleg elfelejtették hígítani az erösen mérgező hatású nadragulyát. Vannak olyan készítmények, amelyeket helytelenül neveznek homeopátiás szernek a nem megfelelő hígítás miatt. A homeopátiás készítmények tartalmazhatnak olyan hatóanyagot, amely nincs megjelölve a fiolán. Nemrégen például penicillint mutattak ki egy homeopátiás készítményben. Könynyủ így antibakteriális hatást elérni. Egy penicillinérzékenységgel rendelkező emberre viszont komoly veszélyt jelenthet egy ilyen szer fogyasztása. Az áltudományos módszerek jelenléte a gyógyító praxisban árt az orvoslás és a tudomány tekintélyének, nem beszélve arról, hogy a homeopátiás szerek vásárlása nem más, mint pénzkidobás az ablakon.

\section{MIÉRT HISZNEK SOKAN A HOMEOPÁTIÁBAN?}

Az irracionális gondolkodás legfőbb okai a tudatlanság, az ismerethiány és egyfajta genetikainak tűnő vonzalom a miszticizmus és az ezotéria iránt. Az emberek többségétől távol áll a tudományos látásmód, sőt gyakran a logikus gondolkodás is. Az iskola adatcentrikus oktatási rendszere nem tanít meg az értelmes gondolkodásra, és sok fontos ténnyel sem ismertet meg bennünket. Evolúciós örökségünk lehet az az attitűd, hogy ahelyett, hogy mi magunk járnánk utána a fontos dolgoknak, megbízunk általunk hitelesnek vélt személyekben, és követjük a közösségi véleményeket. Ha azt állítja a szomszéd, egy rokon vagy egy Facebook-ismerős, hogy az Emőke a homeopátiától gyógyult, akkor ezt készpénznek vesszük. Az elménk ráadásul rendkívül elfogult. Ha valamit a fejünkbe veszünk, igen nehezen változtatjuk meg a véleményünket, gyakran a legnyilvánvalóbb cáfolatok felett is elsiklunk, s kizárólag az elképzeléseinket támogató dolgokra fókuszálunk. Ha sikerül e véleményt konspirációs elméletekkel is megtámogatni, nincs az az erö, amely ki tudna mozdítani az agyunkból egy fixa ideát. Leggyakrabban a gyógyszeripart vélik összeesküdni az orvostársadalommal, akiknek érdeke, hogy minél betegebbek legyünk, hiszen így több pénzt zsebelhetnek be. Ezért gátolja a gyógyszeripar a valóban hatásos gyógyszerek (például a homeopátiás szerek) forgalmazását, sőt, sokan úgy vélik, ez a „maffia” egyenesen mérgezi az embereket az alantas anyagi megfontolások miatt. Az elme szubjektivitásának további bizonyítéka az a tény, hogy a konvencionális és a homeopátiás szereket párhuzamosan szedők közül sokan kizárólag ez utóbbinak tulajdonítják a gyógyító hatást. Ráadásul a betegségek többsége magától gyógyul. Ha eközben homeopátiás szereket szedtünk, úgy vélhetjük, hogy e szereknek köszönhető a jótékony hatás. A placebohatás szintén valódi gyógyhatásúnak tűnik, pedig igen gyakran csak a betegségtudatunk javul. A legtöbben nem tudják, hogyan készül egy homeopátiás szer, s mik e módszer elméleti alapjai, ezért nem is gondolkodnak arról, értelmes 
dologról lehet-e szó. Továbbá, komoly betegség esetén hinni szeretnénk a gyógyulásban. Az orvosi rendelök rideg légkörével és a túlhajszolt orvosok türelmetlenségével szemben a homeopaták ráérö, joviális mosolya áll szemben. Ráadásul az orvos a valós helyzetet tárja fel a várható következményekkel együtt, amely nem versenyképes a homeopata orvos határtalan optimizmusával.

\section{UTósZó}

A homeopátia egy áltudományos módszer, amely nem rendelkezik terápiás hatással a placeboeffektuson túl. Ennek ellenére a fejlett országokban engedélyezik a gyógyításban való alkalmazását, sőt van ahol az állami vagy a magánbiztosítók finanszírozzák a használatát. Egyes országokban még orvosi diploma sem szükséges a gyakorlásához. Ez részben jó, mert nem degradálja az orvosi hivatást, másrészt rossz, mert a páciens így egy sarlatán kezei közé kerülhet, s egy komoly betegség felfedezetlen vagy kezeletlen maradhat. Egy orvos, ha lelkiismeretes, a müködő terápiát is képes alkalmazni. A világ szeme a fejlett országokon van, vajon Ausztrália, az USA vagy az EU lesz az első, aki számon kéri a homeopátián a hatásosságot. A homeopátiának csupán elsőnek kellene lennie a sorban: a teljes kínai medicina, az ájurvédikus gyógyászat, a reiki és társaik szintén a hatástalan áltudományos eljárások közé tartoznak. Ideje ennek hangot is adni, ha lehet, jogi paragrafusok által is megtámogatva.

\section{IRODALOM}

Altunc, U. - Pittler, M. H. - Ernst, E. (2007): Homeopathy for Childhood and Adolescence Ailments: Systematic Review of Randomized Clinical Trials. PubMed Health, https://www.ncbi. nlm.nih.gov/pubmedhealth/PMH0023952/

Ernst, E. (2002): A Systematic Review of Systematic Reviews of Homeopathy. British Journal of Clinical Pharmacology, 54, 6, 577-582. DOI: 10.1046/j.1365-2125.2002.01699.x, https:// bpspubs.onlinelibrary.wiley.com/doi/full/10.1046/j.1365-2125.2002.01699.x

Goldacre, B. (2012): What Doctors Don't Know about the Drugs They Prescribe. TEDMED, https://www.youtube.com/watch?v=RKmxL8VYy0M

McCarney, R. W. - Lasserson, T. J. - Linde, K. (1998): An Overview of Two Cochrane Systematic Reviews of Complementary Treatments for Chronic Asthma: Acupuncture and Homeopathy. Respiratory Medicine, 8, 687-696. DOI: 10.1016/j.rmed.2004.05.005, https://www.resmedjournal.com/article/S0954-6111(04)00210-0/fulltext

Mészáros Á. (2014): Szisztematikus irodalom-elemzés, metaanalízis. Gyógyszerügyi szervezéstan, 2014. március 24. http://semmelweis.hu/gyogyszertar/files/2014/03/MeszarosAgnes_ Sziszt_irod_elemzes_2014.pdf

Milazzo, S. - Russell, N. - Ernst, E. (2006): Efficacy of Homeopathic Therapy in Cancer Treatment. European Journal of Cancer, 42, 3, 282-289. DOI: 10.1016/j.ejca.2005.09.025 
MTA (2015): Azonos elbirálást javasol a homeopátiás szerek és a gyógyszerek esetében az MTA Orvosi Tudományok Osztálya. 2015. 11. 09. http://old.mta.hu/mta_hirei/azonos-elbiralast-javasol-a-homeopatias-szerek-es-a-gyogyszerek-eseteben-az-mta-orvosi-tudomanyok-osztalya-137017/

MTA (2017): Homeopátia: hasznos vagy ártalmas? Új állásfoglalás európai tudósoktól. 2017. 09. 20. http://mta.hu/tudomany_hirei/homeopatia-hasznos-vagy-artalmas-uj-allasfoglalas-europai-tudosoktol-108033

NHMRC (2015): NHMRC Statement on Homeopathy and NHMRC Information Paper - Evidence on the Effectiveness of Homeopathy for Treating Health Conditions. https://www.nhmrc.gov. $\mathrm{au} /$ guidelines-publications/cam02

Posadzki, P. - Alotaibi, A. - Ernst, E. (2012): Adverse Effects of Homeopathy: A Systematic Review of Published Case Reports and Case Series. International Journal of Clinical Practice, 665, 12, 1178-1188. DOI: 10.1111/ijcp.12026, https://onlinelibrary.wiley.com/doi/full/10.1111/ ijcp. 12026

Royal Swedish Academy of Sciences (2015): New Academy Statement on Homeopathic Products. 12 May 2015. https://www.kva.se/en/nyheter/remissvar-om-homeopatiska-lakemedel

Shang, A- - Huwiler-Müntener, K. - Nartey, L. (2005): Are the Clinical Effects of Homoeopathy Placebo Effects? Comparative Study of Placebo-controlled Trials of Homoeopathy and Allopathy. The Lancet, 366, 9487, 726-432. DOI: 10.1016/S0140-6736(05)67177-2, https://www. thelancet.com/journals/lancet/article/PIIS0140-6736(05)67177-2/fulltext

Vickers, A. J. - Smith, C. (2006): Homoeopathic Oscillococcinum for Preventing and Treating Influenza and Influenza-like Syndromes. Cochrane Database of Systematic Reviews, 19, 3, CD001957. DOI: 10.1002/14651858.CD001957.pub3

URL1: https://en.wikipedia.org/wiki/Jacques_Benveniste

URL2: https://hu.wikipedia.org/wiki/James_Randi

URL3: https://hu.wikipedia.org/wiki/Luc_Montagnier

URL4: https://hu.wikipedia.org/wiki/Polimer\%C3\%A1z-1\%C3\%A1ncreakci\%C3\%B3 